Research Paper

\title{
Systematic Correlation Analyses of Circulating Tumor Cells with Clinical Variables and Tumor Markers in Lung Cancer Patients
}

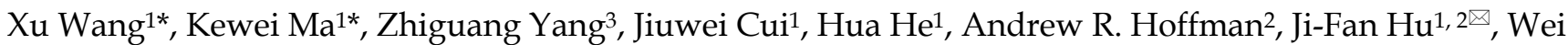 \\ $\mathrm{Li}^{1 凶}$ \\ 1. Cancer and Stem Cell Center, First Affiliated Hospital, Jilin University, Changchun, Jilin 130061, P.R. China; \\ 2. Stanford University Medical School, Palo Alto Veterans Institute for Research, Palo Alto, CA94304, USA; \\ 3. Division of Thoracic Surgery, First Affiliated Hospital, Jilin University, Changchun, Jilin 130061, P.R. China. \\ * These are co-first authors. \\ $\square$ Corresponding authors: Wei Li, M.D., Ph.D., CancerCenter, First Affiliated Hospital, Jilin University, Changchun, Jilin 130061, P.R. China, e-mail: \\ jdyylw@163.com or Ji-Fan Hu, M.D., Ph.D., VA Palo Alto Health Care System, Palo Alto, CA 94304, USA. Tel: 650-493-5000, x63175, Fax: 650-725-7085, E-mail:
} Jifan@stanford.edu

(C) Ivyspring International Publisher. This is an open access article distributed under the terms of the Creative Commons Attribution (CC BY-NC) license (https://creativecommons.org/licenses/by-nc/4.0/). See http://ivyspring.com/terms for full terms and conditions.

Received: 2016.10.22; Accepted: 2017.03.06; Published: 2017.09.05

\begin{abstract}
Measurement of circulating tumor cells (CTC) offers promise as a clinical biomarker to monitor disease status, therapeutic response, and progression in cancer patients. However, its clinical value in lung cancer patients has not been fully explored. We systematically evaluate the association of CTCs with clinical variables and tumor markers in a cohort of lung cancer patients. Using the CELLSEARCH System, CTCs were detected in both small cell lung cancer (SCLC) and non-small cell lung cancer (NSCLC) patients prior to therapy. Univariate analysis revealed that detection of CTC was related to histology, stage, tumor size, invasiveness, and lymphatic metastasis. CTCs were associated with distant metastases in NSCLC, but not in SCLC. Using multivariate analysis, we found that CTCs were independently correlated with disease stage, SCLC, and elevated serum neuron-specific enolase (NSE). These data suggest that CTCs are more likely to be detected in patients with stage IV disease and with SCLC, and that elevated serum NSE predicts the presence of CTCs.
\end{abstract}

Key words: Lung cancer, circulating tumor cells, serum neuron-specific enolase, epidemiologic factors, metastasis.

\section{Introduction}

Primary lung cancer is the leading cause of cancer-related death worldwide ${ }^{1}$. The vast majority of cancer-related deaths are due to metastasis, or spreading of the disease beyond the primary tumor site. Metastasis occurs when cells are shed from the primary tumor and circulate in the blood. It is these circulating tumor cells (CTCs) that constitute the seeds for subsequent growth of metastatic tumors in distant organs, such as the liver, brain, or bone marrow.

Cancer biomarkers may reveal important clues about clinical course or outcome. CTCs are candidate biomarkers that may be able to assess disease progression before patients become symptomatic. The prognostic utility of CTCs in lung cancer has been investigated $^{2-9}$. Early stage NSCLC patients who had detectable CTC were most likely to develop subsequent metastatic recurrence ${ }^{10}$. It is also possible that CTCs harbor molecular information that cannot be obtained from other serum tumor markers and that may be useful in guiding decisions involving the administration of targeted therapies.

However, there is controversy regarding the incidence and clinical significance of CTCs in NSCLC, 
particularly in Chinese patients. While some studies have reported that detection of CTCs was significantly associated with shorter survival2-3, 6-8, other studies have failed to identify any association between the presence of CTCs and prognosis9. Recently, a meta-analysis, which included 20 studies comprised of 1576 patients, showed that the presence of CTCs indicated a poor prognosis in patients with NSCLC ${ }^{11}$.

Recently, the US Food and Drug Administration approved the CELLSEARCH ${ }^{\circledR}$ System (Veridex, Raritan, NJ, USA) as a novel technology to detect $\mathrm{CTCs}^{12-13}$. The clinical value of CTCs in lung cancer patients has not been fully explored. The major objective of this study was to assess whether the presence of CTCs in lung cancer patients prior to therapy correlated with other clinical parameters.

\section{Materials and methods}

\section{Patients}

Patients were treated at the First Hospital of Jilin University (Changchun, Jilin, China). The study was approved by the Ethics Committee of the First Hospital of Jilin Medical University, and conducted according to the World Medical Association Declaration of Helsinki on ethical principles for medical research involving human subjects. Patients signed a written informed consent prior to the initiation of the study.

Patients had histologically confirmed lung cancer and did not have a previous cancer history. They had not yet undergone any treatment, including surgery, radiotherapy, chemotherapy or any other anti-cancer therapy. Thoracic CT scan, abdominal CT scan, brain MRI and bone scanning were used for TNM staging ( $7^{\text {th }}$ edition, 200914), with which SCLC patients were further stratifiedby stages I, II, and III for correlation analysis of SCLC stages with CTC.

\section{CTC analysis}

Peripheral blood samples were collected for CTC analysis within 7 days prior to the initiation of treatment. Measurements prior to treatment were considered baseline. Blood samples were collected in $10 \mathrm{ml}$ Cell Save Preservation tubes, stored at room temperature, and processed within $96 \mathrm{hr}$ of collection, according to the manufacturer's instructions (Veridex). CTC analysis was performed using the CELLSEARCH ${ }^{\circledR}$ System (Veridex) as previously described $^{12-13}$. Ferrofluid nanoparticles coated with a polymer layer carrying biotin analogues and conjugated with antibodies against epithelial cell adhesion molecule (EpCAM) were used to initially capture putative CTCs, which were then magnetically separated from the remaining blood components. The isolated cells were fluorescently stained with specific antibody conjugates, such as CD45 (a leukocyte marker) and cytokeratins 8, 18, and 19 (CKs), and imaged for record. To be considered a CTC, a cell must be CD45 negative, contain a nucleus, and exhibit positive staining for cytoplasmic CKs.

\section{Serum tumor marker analysis}

Determination of serum tumor markers was performed on the Luminex 200 System with $x M A P \circledR$ technology (Luminex; Austin, TX, USA), including carcinoembryonic antigen (CEA), cancer antigen (CA) 19-9, CA-125, squamous cell carcinoma antigen (SCC-Ag), cytokeratin-19 fragments antigen 21-1 (CYFRA21-1), and neuron-specific enolase (NSE). The upper limits of normal values are $5 \mathrm{ng} / \mathrm{mL}$ for CEA, $35 \mathrm{U} / \mathrm{mL}$ for CA19-9, $35 \mathrm{U} / \mathrm{mL}$ for CA-125, 1.5 $\mathrm{ng} / \mathrm{mL}$ for SCC-Ag, $5 \mathrm{ng} / \mathrm{mL}$ for CYFRA21-1, and 20 $\mathrm{ng} / \mathrm{mL}$ for NSE.

\section{Statistical analysis}

Univariate Fisher test analysis and multivariate logistic regression were used to evaluate the relationships between clinicopathologic data and CTC count thresholds in lung cancer patients, as well as the association between tumor markers and CTC count thresholds. In the multivariate logistic regression analysis, all categorical variables were set as dummy variables. The first category of each variable was selected as the baseline. All analyses were performed with SPSS v19.0 software (SPSS, Inc.; Chicago, IL, USA). A $P$-value $<0.05$ was considered statistically significant.

\section{Results}

\section{CTCs are detected in both NSCLC and SCLC patients}

Clinical parameters, CTC count, and tumor markers are shown in Table 1. Patients were simultaneously tested for other serum markers typically used in the clinical evaluation of lung cancer. Levels of serum CEA, NSE, Cyfra21-1, CA19-9, CA-125, and SCC-Ag were detectable in 173, 171, 173, 126, 118, and 122 patients, respectively. The median follow-up for all patients was 1 yr but we cannot yet evaluate survival outcomes.

Among patients enrolled in the study, 169 patients had NSCLC (63.8\%) and 96 patients had SCLC (36.2\%). CTCs were detected in $32.8 \%$ patients, with 40 cases in patients with NSCLC and 47 cases in patients with SCLC. A typical image of a CTC is shown in Figure 1. 

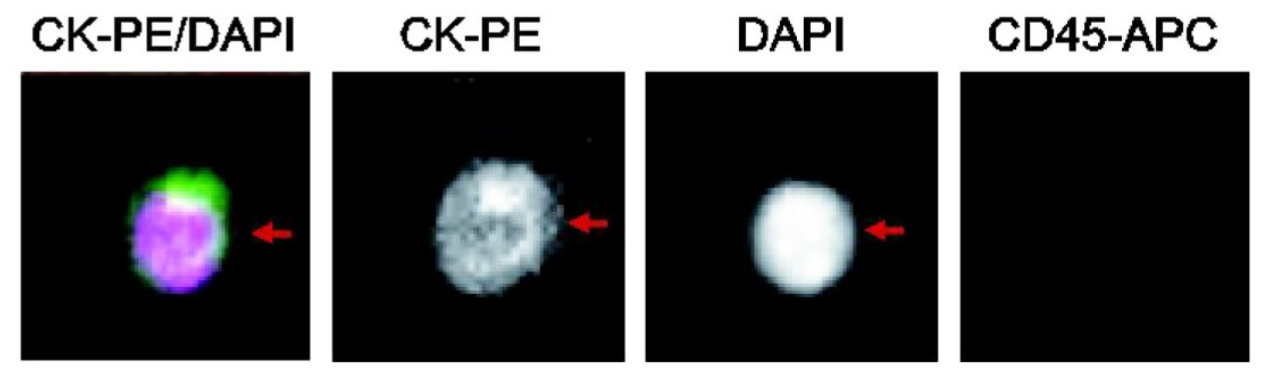

Figure 1. Immunostaining of a single lung cancer CTC isolated from peripheral blood. Positive immunomagnetic selection with anti-EpCAM Ab was followed by morphological confirmation with staining for cytokeratins (cytoplasm), DAPI (nucleus), and CD45 (negative).

Table 1. Clinical characteristics, CTC count, and tumor markers of lung cancer patients.

\begin{tabular}{lll}
\hline Characteristics & & Number $(\%)$ \\
\hline Gender & Male & $174(65.7 \%)$ \\
Age & Female & $91(34.3 \%)$ \\
& $<60$ & $102(38.5 \%)$ \\
Histology & $\geq 60$ & $163(61.5 \%)$ \\
& NSCLC & $169(63.8 \%)$ \\
Smoking status & SCLC & $96(36.2 \%)$ \\
& Never & $105(39.6 \%)$ \\
Clinical Stage & Former & $47(17.7 \%)$ \\
& Current & $113(42.6 \%)$ \\
& I & $17(6.4 \%)$ \\
CTC count & II & $19(7.2 \%)$ \\
& III & $97(36.6 \%)$ \\
& IV & $126(47.5 \%)$ \\
CEA & $\geq 1$ & $87(32.8 \%)$ \\
& $\geq 2$ & $58(21.9 \%)$ \\
NSE & $\geq 5$ & $41(15.5 \%)$ \\
& Elevated & $77(43.8 \%)$ \\
Cyfra21-1 & Normal & $96(56.3 \%)$ \\
& Elevated & $53(31.0 \%)$ \\
CA199 & Normal & $118(69.0 \%)$ \\
& Elevated & $62(35.8 \%)$ \\
CA125 & Normal & $111(64.2 \%)$ \\
& Elevated & $16(12.7 \%)$ \\
& Normal & $110(87.3 \%)$ \\
& Elevated & $45(38.1 \%)$ \\
& Normal & $73(61.9 \%)$ \\
& Elevated & $7(5.7 \%)$ \\
& Normal & $115(94.3 \%)$ \\
\hline
\end{tabular}

\section{Univariate analysis of CTC count with clinico-pathological variables}

No significant differences were observed for the association between any threshold CTC count and gender, age ( $\leq 60$ or $>60 \mathrm{yr})$, or smoking status. However, an association was found with histology. Of the 87 patients who had detectable CTCs (CTC count of $\geq 1 / 7.5 \mathrm{ml})$, 40 were histologically categorized as NSCLC $(23.7 \%)$ and 47 as SCLC $(49.0 \%)$ (Table 2). The predominance of NSCLC patients was observed at all CTC thresholds (CTCs $\geq 1$, 2or5 $/ 7.5 \mathrm{ml})(P<0.05)$.

The presence of CTCs was associated with advanced tumor stage $(P<0.05$ for CTC thresholds $\geq 1$ and $2 / 7.5 \mathrm{ml}$ blood); the percentage of lung cancer patients who had detectable CTC increased from $1 / 17$
$(5.9 \%)$ at stage I to $46 / 126(36.5 \%)$ at stage IV (Table 2).

Tumor size and invasiveness, and local lymphatic metastasis were all associated with CTC count at thresholds $\geq 1$ or $5 / 7.5 \mathrm{ml}(P<0.05)$, respectively (Table 2). The number of patients with detectable CTCs increased from $14 / 40(35.0 \%)$ at T1 to $27 / 58$ (46.6\%) at T4 (CTC threshold $\geq 1 / 7.5 \mathrm{ml}$ blood). Lymphatic metastasis was found in $4 / 40$ (10.0 \%) patients at N0 and in $19 / 76(25.0 \%)$ patients at N3 (CTCs $\geq 5 / 7.5 \mathrm{ml}$ blood). However, no relationship between CTC count and distant metastasis was observed. In patients with NSCLC, distant metastasis was found in $11 / 75(14.7 \%)$ M0 patients compared to 29/94 (30.9\%) M1 patients who had CTCs (CTCs $\geq$ $1 / 7.5 \mathrm{ml}$ blood, $P<0.05$, and CTCs $\geq 2$ and $5 / 7.5 \mathrm{ml}$ blood, $P<0.05)$. However, in patients with SCLC, no statistical difference was observed at any CTC threshold (CTCs $\geq 1,2$ or $5 / 7.5 \mathrm{ml}$ ).

\section{Multivariate analysis demonstrates that CTCs correlate with advanced stage and histology of SCLC}

To identify a patient profile that predicts the presence of detectable CTC, multivariate analysis was performed using age, gender, smoking history, histology, and clinical stage. Lung cancer patients with either stage IV disease or SCLC histology had a higher incidence of detectable CTCs $(\mathrm{P}<0.05$, Table $3)$.

\section{Lung cancer CTCs correlate with serum NSE levels}

No significant correlation was found between lung cancer CTC count and serum tumor markers, CA-125, CA19-9, Cyfra21-1, and SCC-Ag (Table 3), but there was an association of CTCs with serum NSE (Table 4). After adjustment for TNM stage (I, II, III and IV) and histology (SCLC and NSCLC), serum NSE levels were still associated with the CTC count. Results were similar when CTC thresholds $\geq 2$ and 5/7.5 ml were used (Table 5). A similar non-significant trend was also observed with CEA. 
Table 2. Univariate analysis between CTC count (per $7.5 \mathrm{~mL}$ of peripheral blood) and clinical-pathological data.

\begin{tabular}{|c|c|c|c|c|c|c|c|c|c|c|}
\hline \multicolumn{2}{|c|}{ Characteristic } & $\begin{array}{l}<1 \\
(\%)\end{array}$ & $\begin{array}{l}\geq 1 \\
(\%)\end{array}$ & $P$ value & $\begin{array}{l}<2 \\
(\%)\end{array}$ & $\begin{array}{l}\geq 2 \\
(\%)\end{array}$ & $P$ value & $\begin{array}{l}<5 \\
(\%)\end{array}$ & $\begin{array}{l}\geq 5 \\
(\%)\end{array}$ & $P$ Value \\
\hline \multirow[t]{4}{*}{ Gender } & Male & 118 & 56 & & 137 & 37 & & 147 & 27 & \\
\hline & & $(67.8)$ & $(32.2)$ & & (78.7) & (21.3) & & $(84.5)$ & $(15.5)$ & \\
\hline & Female & 60 & 31 & 0.784 & 70 & 21 & 0.756 & 77 & 14 & 1.000 \\
\hline & & $(65.9)$ & $(34.1)$ & & (76.9) & (23.1) & & (84.6) & (15.4) & \\
\hline \multirow[t]{4}{*}{ Age } & $<60$ & 107 & 56 & & 123 & 40 & & 133 & 30 & \\
\hline & & $(65.6)$ & $(34.4)$ & & $(75.5)$ & $(24.5)$ & & (81.6) & $(18.4)$ & \\
\hline & $\geq 60$ & 71 & 31 & 0.591 & 84 & 18 & 0.223 & 91 & 11 & 0.116 \\
\hline & & $(69.6)$ & $(30.4)$ & & $(82.4)$ & (17.6) & & (89.2) & (10.8) & \\
\hline \multirow[t]{4}{*}{ Histology } & NSCLC & 129 & 40 & & 149 & 20 & & 156 & 13 & \\
\hline & & $(76.3)$ & $(23.7)$ & & (88.2) & (11.8) & & (92.3) & (7.7) & \\
\hline & SCLC & 49 & 47 & 0.000 & 58 & 38 & 0.000 & 68 & 28 & 0.000 \\
\hline & & $(51.0)$ & $(49.0)$ & & $(60.4)$ & (39.6) & & (70.8) & $(29.2)$ & \\
\hline \multirow{6}{*}{$\begin{array}{l}\text { Smoking } \\
\text { status }\end{array}$} & Never & 72 & 33 & & 85 & 20 & & 89 & 16 & \\
\hline & & $(68.6)$ & $(31.4)$ & & $(81.0)$ & (19.0) & & (84.8) & $(15.2)$ & \\
\hline & Former & 29 & 18 & & 33 & 14 & & 38 & 9 & \\
\hline & & $(61.7)$ & $(38.3)$ & & $(70.2)$ & (29.8) & & $(80.9)$ & $(19.1)$ & \\
\hline & Current & 77 & 36 & 0.688 & 89 & 24 & 0.337 & 97 & 16 & 0.713 \\
\hline & & $(68.1)$ & $(31.9)$ & & (78.8) & (21.2) & & (85.8) & $(14.2)$ & \\
\hline \multirow[t]{2}{*}{ clinical } & I & 16 & 1 & & 16 & 1 & & 16 & 1 & \\
\hline & & $(94.1)$ & (5.9) & & $(94.1)$ & (5.9) & & (94.1) & (5.9) & \\
\hline \multirow{6}{*}{$\begin{array}{l}\text { TNM } \\
\text { stage }\end{array}$} & II & 16 & 3 & & 19 & 0 & & 19 & 0 & \\
\hline & & $(84.2)$ & $(15.8)$ & & $(100.0)$ & $(0.0)$ & & $(100.0)$ & $(0.0)$ & \\
\hline & III & 64 & 33 & & 74 & 23 & & 80 & 17 & \\
\hline & & $(66.0)$ & $(34.0)$ & & (76.3) & (30.3) & & $(82.5)$ & $(17.5)$ & \\
\hline & IV & 80 & 46 & 0.023 & 94 & 32 & 0.016 & 105 & 21 & 0.153 \\
\hline & & $(63.5)$ & $(36.5)$ & & (74.6) & (25.4) & & (83.3) & $(16.7)$ & \\
\hline \multirow[t]{8}{*}{$\mathrm{T}$} & $\mathrm{T} 1$ & 26 & 14 & & 32 & 8 & & 37 & 3 & \\
\hline & & $(65.0)$ & $(35.0)$ & & $(80.0)$ & $(20.0)$ & & $(92.5)$ & (7.5) & \\
\hline & $\mathrm{T} 2$ & 67 & 16 & & 72 & 11 & & 74 & 9 & \\
\hline & & $(80.7)$ & (19.3) & & (86.7) & (13.3) & & $(89.2)$ & $(10.8)$ & \\
\hline & $\mathrm{T} 3$ & 39 & 22 & & 47 & 14 & & 51 & 10 & \\
\hline & & $(63.9)$ & $(36.1)$ & & $(77.0)$ & $(23.0)$ & & $(83.6)$ & $(16.4)$ & \\
\hline & $\mathrm{T} 4$ & 31 & 27 & 0.006 & 39 & 19 & 0.050 & 44 & 14 & 0.091 \\
\hline & & $(53.4)$ & $(46.6)$ & & $(67.2)$ & (32.8) & & (75.9) & $(24.1)$ & \\
\hline \multirow[t]{8}{*}{$\mathrm{N}$} & N0 & 32 & 8 & & 35 & 5 & & 36 & 4 & \\
\hline & & $(80.0)$ & $(20.0)$ & & (87.5) & (12.5) & & $(90.0)$ & $(10.0)$ & \\
\hline & N1 & 19 & 6 & & 23 & 2 & & 24 & 1 & \\
\hline & & $(76.0)$ & $(24.0)$ & & $(92.0)$ & $(8.0)$ & & $(96.0)$ & $(4.0)$ & \\
\hline & N2 & 75 & 44 & & 90 & 29 & & 102 & 17 & \\
\hline & & $(63.0)$ & $(37.0)$ & & (75.6) & $(24.4)$ & & (85.7) & $(14.3)$ & \\
\hline & N3 & 48 & 28 & 0.150 & 54 & 22 & 0.058 & 57 & 19 & 0.043 \\
\hline & & $(63.2)$ & $(36.8)$ & & (71.1) & (28.9) & & $(75.0)$ & $(25.0)$ & \\
\hline \multirow[t]{4}{*}{ M } & M0 & 98 & 41 & & 113 & 26 & & 119 & 20 & \\
\hline & & $(70.5)$ & (29.5) & & (81.3) & (18.7) & & $(85.6)$ & $(14.4)$ & \\
\hline & M1 & 80 & 46 & 0.241 & 94 & 32 & 0.234 & 105 & 21 & 0.615 \\
\hline & & $(63.5)$ & $(36.5)$ & & (74.6) & (25.4) & & (83.3) & $(16.7)$ & \\
\hline \multirow[t]{4}{*}{ NSCLC } & M0 & 64 & 11 & & 73 & 2 & & 73 & 2 & \\
\hline & & $(85.3)$ & $(14.7)$ & & (97.3) & $(2.7)$ & & $(97.3)$ & $(2.7)$ & \\
\hline & M1 & 65 & 29 & 0.018 & 76 & 18 & 0.001 & 83 & 11 & 0.040 \\
\hline & & $(69.1)$ & $(30.9)$ & & $(80.9)$ & (19.1) & & $(88.3)$ & $(11.7)$ & \\
\hline \multirow[t]{4}{*}{ SCLC } & M0 & 34 & 30 & & 40 & 24 & & 46 & 18 & \\
\hline & & $(53.1)$ & $(46.9)$ & & $(62.5)$ & (37.5) & & (71.9) & $(28.1)$ & \\
\hline & M1 & 15 & 17 & 0.666 & 18 & 14 & 0.659 & 22 & 10 & 0.814 \\
\hline & & $(46.9)$ & $(53.1)$ & & (56.3) & $(43.8)$ & & $(68.8)$ & $(31.3)$ & \\
\hline
\end{tabular}

\section{Discussion}

The measurement of CTCs offers potential utility as a prognostic, predictive, and/or pharmacodynamic biomarker ${ }^{12,}$ 15-19. While multiple studies have examined the prevalence and prognostic utility of CTCs in lung cancer-9, 11, only a few have addressed whether CTCs are related to other clinical parameters. This information may be useful in order to identify subgroups of lung cancer patients in whom CTC status might be therapeutically useful. Our data show that CTCs were independently correlated with three clinical characteristics: advanced stage IV disease, SCLC histology, and elevated serum NSE. 
Univariate analysis revealed that CTC count significantly increased in parallel with TNM stage (from I to IV), tumor size and invasiveness, lymphatic metastasis, and histology. CTCs have been shown to display sensitivity and specificity in distinguishing clinical stage as well as histology (SCLC versus NSCLC) in other studies ${ }^{10}$.

The CTC has been recently recommended by the American Society of Clinical Oncology (ASCO) as a potentially acceptable tumor marker for breast cancer patients ${ }^{20}$. In our study, a rigorous analysis was performed to determine the relevance of CTC count to standard tumor markers used in the diagnosis and clinical management of lung cancer patients. Although CTCs were found to correlate with levels of CYFRA21-1 in a previous, smaller study ${ }^{21}$, serum NSE was the only tumor marker found to be associated with CTCs in our study. Other investigators have reported that serum NSE levels were associated with prognosis ${ }^{22}$.The biological basis for the correlation between lung cancer CTCs and NSE will be the focus of future studies.

Others have previously shown that CTCs are correlated with the presence of distant metastasis ${ }^{23}$ in lung cancer ${ }^{24}$. However, no relationship between any
CTC threshold and distant metastasis was seen in our study. However, when cases with distant metastasis were divided on the basis of histologic subtype (NSCLC or SCLC), the presence of CTC was found to be associated with distant metastasis only in NSCLC.

Table 3. Multivariate analysis of the CTC positive model with adjusted odds ratios and $95 \% \mathrm{Cl}$

\begin{tabular}{llll}
\hline Risk factors & $\operatorname{Exp}(\mathrm{B})$ & $95 \% \mathrm{CI}$ & P-value \\
\hline Gender & & & \\
Female & 1.00 & Reference & - \\
Male & 1.250 & $0.654-2.387$ & 0.499 \\
Age & & & \\
$\geq 60$ & 1.00 & Reference & - \\
$<60$ & 0.784 & $0.434-1.418$ & 0.421 \\
Smoking history & & & 0.465 \\
Never & 1.00 & Reference & - \\
Ever & 1.627 & $0.714-3.705$ & 0.246 \\
Current & 1.063 & $0.532-2.124$ & 0.862 \\
Clinical stage & & & 0.058 \\
I & 1.00 & Reference & - \\
II & 3.270 & $0.295-36.227$ & 0.334 \\
III & 6.001 & $0.742-48.566$ & 0.093 \\
IV & 9.377 & $1.182-74.386$ & 0.034 \\
Histology & & & \\
NSCLC & 1.00 & Reference & - \\
SCLC & 3.002 & $1.656-5.444$ & 0.000 \\
\hline
\end{tabular}

Table 4. Associations between CTC count and tumor markers.

\begin{tabular}{|c|c|c|c|c|c|c|c|c|c|c|}
\hline Characteristic & & $\begin{array}{l}<1 \\
(\%)\end{array}$ & $\begin{array}{l}\geq 1 \\
(\%)\end{array}$ & $P$ value & $\begin{array}{l}<2 \\
(\%)\end{array}$ & $\begin{array}{l}\geq 2 \\
(\%)\end{array}$ & $P$ value & $\begin{array}{l}<5 \\
(\%)\end{array}$ & $\begin{array}{l}\geq 5 \\
(\%)\end{array}$ & $P$ value \\
\hline \multirow[t]{2}{*}{ CEA } & Elevated & $\begin{array}{l}46 \\
(59.7)\end{array}$ & $\begin{array}{l}31 \\
(40.3)\end{array}$ & & $\begin{array}{l}53 \\
(68.8)\end{array}$ & $\begin{array}{l}24 \\
(31.2)\end{array}$ & & $\begin{array}{l}59 \\
(76.6)\end{array}$ & $\begin{array}{l}18 \\
(23.4)\end{array}$ & \\
\hline & Normal & $\begin{array}{l}73 \\
(73.7)\end{array}$ & $\begin{array}{l}26 \\
(26.3)\end{array}$ & 0.053 & $\begin{array}{l}80 \\
(80.8)\end{array}$ & $\begin{array}{l}19 \\
(19.2)\end{array}$ & 0.078 & $\begin{array}{l}86 \\
(86.9)\end{array}$ & $\begin{array}{l}13 \\
(13.1)\end{array}$ & 0.110 \\
\hline \multirow[t]{2}{*}{ NSE } & Elevated & $\begin{array}{l}26 \\
(49.1)\end{array}$ & $\begin{array}{l}27 \\
(50.9)\end{array}$ & & $\begin{array}{l}28 \\
(52.8)\end{array}$ & $\begin{array}{l}25 \\
(47.2)\end{array}$ & & $\begin{array}{l}36 \\
(67.9)\end{array}$ & $\begin{array}{l}17 \\
(32.1)\end{array}$ & \\
\hline & Normal & $\begin{array}{l}91 \\
(77.1)\end{array}$ & $\begin{array}{l}27 \\
(22.9)\end{array}$ & 0.000 & $\begin{array}{l}103 \\
(87.3)\end{array}$ & $\begin{array}{l}15 \\
(12.7)\end{array}$ & 0.000 & $\begin{array}{l}106 \\
(89.8)\end{array}$ & $\begin{array}{l}12 \\
(10.2)\end{array}$ & 0.001 \\
\hline \multirow[t]{2}{*}{ Cyfra21-1 } & Elevated & $\begin{array}{l}42 \\
(67.7)\end{array}$ & $\begin{array}{l}20 \\
(32.3)\end{array}$ & & $\begin{array}{l}47 \\
(75.8)\end{array}$ & $\begin{array}{l}15 \\
(24.2)\end{array}$ & & $\begin{array}{l}52 \\
(83.9)\end{array}$ & $\begin{array}{l}10 \\
(16.1)\end{array}$ & \\
\hline & Normal & $\begin{array}{l}75 \\
(67.6)\end{array}$ & $\begin{array}{l}36 \\
(32.4)\end{array}$ & 1.000 & $\begin{array}{l}84 \\
(75.7)\end{array}$ & $\begin{array}{l}27 \\
(24.3)\end{array}$ & 1.000 & $\begin{array}{l}91 \\
(82.0)\end{array}$ & $\begin{array}{l}20 \\
(18.0)\end{array}$ & 0.836 \\
\hline \multirow[t]{2}{*}{ CA199 } & Elevated & $\begin{array}{l}12 \\
(75.0)\end{array}$ & $\begin{array}{l}4 \\
(25.0)\end{array}$ & & $\begin{array}{l}12 \\
(75.0)\end{array}$ & $\begin{array}{l}4 \\
(25.0)\end{array}$ & & $\begin{array}{l}13 \\
(81.2)\end{array}$ & $\begin{array}{l}3 \\
(18.8)\end{array}$ & \\
\hline & Normal & $\begin{array}{l}81 \\
(73.6)\end{array}$ & $\begin{array}{l}29 \\
(26.4)\end{array}$ & 1.000 & $\begin{array}{l}87 \\
(79.1)\end{array}$ & $\begin{array}{l}23 \\
(20.9)\end{array}$ & 0.747 & $\begin{array}{l}93 \\
(84.5)\end{array}$ & $\begin{array}{l}17 \\
(15.5)\end{array}$ & 0.719 \\
\hline \multirow[t]{2}{*}{ CA125 } & Elevated & $\begin{array}{l}33 \\
(73.3)\end{array}$ & $\begin{array}{l}12 \\
(26.7)\end{array}$ & & $\begin{array}{l}33 \\
(73.3)\end{array}$ & $\begin{array}{l}12 \\
(26.7)\end{array}$ & & $\begin{array}{l}36 \\
(80.0)\end{array}$ & $\begin{array}{l}9 \\
(20.0)\end{array}$ & \\
\hline & Normal & $\begin{array}{l}55 \\
(75.3)\end{array}$ & $\begin{array}{l}18 \\
(24.1)\end{array}$ & 0.830 & $\begin{array}{l}60 \\
(82.2)\end{array}$ & $\begin{array}{l}13 \\
(17.8)\end{array}$ & 0.258 & $\begin{array}{l}64 \\
(87.7)\end{array}$ & $\begin{array}{l}9 \\
(12.3)\end{array}$ & 0.298 \\
\hline \multirow[t]{2}{*}{ SCC-Ag } & Elevated & $\begin{array}{l}5 \\
(71.4)\end{array}$ & $\begin{array}{l}2 \\
(28.6)\end{array}$ & & $\begin{array}{l}6 \\
(85.7)\end{array}$ & $\begin{array}{l}1 \\
(14.3)\end{array}$ & & $\begin{array}{l}6 \\
(85.7)\end{array}$ & $\begin{array}{l}1 \\
(14.3)\end{array}$ & \\
\hline & Normal & $\begin{array}{l}86 \\
(74.8)\end{array}$ & $\begin{array}{l}29 \\
(25.2)\end{array}$ & 1.000 & $\begin{array}{l}91 \\
(79.1)\end{array}$ & $\begin{array}{l}24 \\
(20.9)\end{array}$ & 1.000 & $\begin{array}{l}98 \\
(85.2)\end{array}$ & $\begin{array}{l}17 \\
(14.8)\end{array}$ & 1.000 \\
\hline
\end{tabular}

Using tumor progression models, it has been reported that tumor cells can spread to distant sites even at pathologically early stages in tumor development ${ }^{25-26}$. In support of this finding, tumor cells have been detected in the peripheral blood of patients with early stage malignant epithelial 
tumors ${ }^{27}$. In a prospective study of lung cancer patients ${ }^{10}$, CTCs were detected in 17/88 (19.3\%) clinical stage I patients where distant metastases (all intrapulmonary metastases) were confirmed in two of 17 cases. Similarly, we found that CTCs were detected in $1 / 17(5.9 \%)$ and $3 / 19(15.8 \%)$ stage I and stage II patients, respectively. Long-term follow-up of these patients may determine whether the CTC count can eventually be correlated with the development of micrometastasis which ultimately leads to postoperative recurrence.

Finally, our multivariate analysis revealed that the detection of CTCs was correlated with histologic type (NSCLC and SCLC) and TNM stage (I, II, III and IV), but no significant correlation was observed with age, gender, and smoking status. In summary, our data indicate that CTCs are most likely to be found in patients who present with any one of three clinical characteristics: SCLC histology, stage IV disease, or elevated serum levels of NSE. A longer follow-up of the present cohort of patients using CTC testing may lead to a better understanding of disease progression.

Table 5. Association between CTC count and serum NSE levels.

\begin{tabular}{lllll}
\hline CTC count & NSE level & Exp (B) & $95 \%$ CI & P-value* \\
\hline CTC $\geq 1$ & Normal & 1.00 & Reference & - \\
& Elevated & 2.953 & $1.302-6.698$ & 0.010 \\
CTC $\geq 2$ & Normal & 1.00 & Reference & - \\
& Elevated & 4.446 & $1.785-11.070$ & 0.001 \\
CTC $\geq 5$ & Normal & 1.00 & Reference & - \\
& Elevated & 2.914 & $1.072-7.922$ & 0.036 \\
\hline
\end{tabular}

${ }^{*} P$ value was adjusted by TNM stage (I, II, III and IV) and histology (SCLC and NSCLC).

\section{Acknowledgements}

This work was supported by the National Natural Science Foundation of China grants (\#81501962), Youth fund of the first hospital of Jilin university (JDYY52015003) to X.W.; The National Natural Science Foundation of China grants (\#81071920, \#81372835), Jilin Provincial Science and Technology Department Grant (11ZDGG003), the Key Clinical Project of the Ministry of Health of the People's Republic of China Grant (\#2001133) to W.L.; The National Natural Science Foundation of China grants (\#81372870) to K.W.M; NIH grant (1R43 CA103553-01), California Institute of Regenerative Medicine (CIRM) grant (RT2-01942), Jilin International Collaboration Grant (\#20120720), the National Natural Science Foundation of China grant (\#81272294, \#31430021) to J.F.H;

\section{Competing Interests}

The authors have declared that no competing interest exists.

\footnotetext{
interest exists.
}

\section{References}

1. Alberg AJ, Fordand JG, Samet JM. American College of Chest P. Epidemiology of lung cancer: ACCP evidence-based clinical practice guidelines (2nd edition). Chest 2007; 132:29-55.

2. Krebs MG, Sloane R, Priest L et al. Evaluation and prognostic significance of circulating tumor cells in patients with non-small-cell lung cancer. J Clin Oncol 2011; 29:1556-1563.

3. Hofman V, Bonnetaud C, Ilie MI et al. Preoperative circulating tumor cell detection using the isolation by size of epithelial tumor cell method for patients with lung cancer is a new prognostic biomarker. Clin CancerRes 2011; 17:827-835.

4. Hiltermann TJ, Pore MM, van den Berg A et al. Circulating tumor cells in small-cell lung cancer: a predictive and prognostic factor. Ann Oncol 2012; 23:2937-2942.

5. Hou JM, Krebs MG, Lancashire L et al. Clinical significance and molecular characteristics of circulating tumor cells and circulating tumor microemboli in patients with small-cell lung cancer. J Clin Oncol 2012; 30:525-532.

6. Hofman V, Ilie MI, Long E et al. Detection of circulating tumor cells as a prognostic factor in patients undergoing radical surgery for non-small-cell lung carcinoma: comparison of the efficacy of the Cell Search Assay and the isolation by size of epithelial tumor cell method. Int J Cancer 2011; 129:1651-1660.

7. Yamashita J, Matsuo A, Kurusu Y, Saishoji T, Hayashi N, Ogawa M. Preoperative evidence of circulating tumor cells by means of reverse transcriptase-polymerase chain reaction for carcinoembryonic antigen messenger RNA is an independent predictor of survival in non-small cell lung cancer: a prospective study. J Thorac Cardiovasc Surg 2002; 124:299-305.

8. Yoon SO, Kim YT, Jung KC, Jeon YK, Kim BH, Kim CW. TTF-1 mRNA-positive circulating tumor cells in the peripheral blood predict poor prognosis in surgically resected non-small cell lung cancer patients. Lung Cancer 2011; 71:209-216.

9. Hirose T, Murata Y, Oki Y et al. Relationship of circulating tumor cells to the effectiveness of cytotoxic chemotherapy in patients with metastatic non-small-cell lung cancer. Oncol Res 2012; 20:131-137.

10. Tanaka F, Yoneda $\mathrm{K}$, Kondo $\mathrm{N}$ et al. Circulating tumor cell as a diagnostic marker in primary lung cancer. Clin Cancer Res 2009; 15:6980-6986.

11. Wang J, Wang K, Xu J, Huang J, Zhang T: Prognostic significance of circulating tumor cells in non-small-cell lung cancer patients: a meta-analysis. PloS one 2013;8: e78070.

12. Cristofanilli M, Budd GT, Ellis MJ et al. Circulating tumor cells, disease progression, and survival in metastatic breast cancer. N Engl J Med 2004; 351:781-791.

13. Allard WJ, Matera J, Miller MC et al. Tumor cells circulate in the peripheral blood of all major carcinomas but not in healthy subjects or patients with nonmalignant diseases. Clin Cancer Res 2004; 10:6897-6904.

14. Postmus PE, Brambilla E, Chansky K et al. The IASLC Lung Cancer Staging Project: proposals for revision of the $\mathrm{M}$ descriptors in the forthcoming (seventh) edition of the TNM classification of lung cancer. J Thorac Oncol 2007; 2:686-93.

15. Mocellin S, Keilholz U, Rossi CR, Nitti D. Circulating tumor cells: the 'leukemic phase' of solid cancers. Trends Mol Med 2006; 12:130-139.

16. Sher YP, Shih JY, Yang PC et al: Prognosis of non-small cell lung cancer patients by detecting circulating cancer cells in the peripheral blood with multiple marker genes. Clin Cancer Res 2005; 11:173-179.

17. Braun S, Naume B. Circulating and disseminated tumor cells. J Clin Oncol 2005; 23:1623-1626.

18. Budd GT, Cristofanilli M, Ellis MJ et al. Circulating tumor cells versus imaging--predicting overall survival in metastatic breast cancer. Clin Cancer Res 2006; 12:6403-6409.

19. Hayes DF, Cristofanilli M, Budd GT et al. Circulating tumor cells at each follow-up time point during therapy of metastatic breast cancer patients predict progression-free and overall survival. Clin Cancer Res 2006; 12:4218-4224.

20. Harris L, Fritsche H, Mennel R et al. American Society of Clinical Oncology 2007 update of recommendations for the use of tumor markers in breast cancer. J Clin Oncol 2007; 25:5287-5312.

21. Chen $\mathrm{Q}, \mathrm{Ge} F, \mathrm{Cui} W$ et al. Lung cancer circulating tumor cells isolated by the EpCAM-independent enrichment strategy correlate with Cytokeratin 19-derived CYFRA21-1 and pathological staging. Clin Chim Acta 2013; 419:57-61.

22. Yu D, Du K, Liu T, Chen G. Prognostic Value of Tumor Markers, NSE, CA125 and SCC, in Operable NSCLC Patients. Int J Mol Sci 2013; 14:11145-11156.

23. Kim MY, Oskarsson T, Acharyya $\mathrm{S}$ et al. Tumor self-seeding by circulating cancer cells. Cell 2009; 139:1315-1326.

24. Hou JM, Krebs M, Ward T et al. Circulating tumor cells as a window on metastasis biology in lung cancer. Am J Pathol 2011; 178:989-996.

25. Husemann Y, Geigl JB, Schubert F et al. Systemic spread is an early step in breast cancer. Cancer cell 2008; 13:58-68.

26. Klein CA. Cancer. The metastasis cascades. Science 2008; 321:1785-1787.

27. Alix-Panabieres C, Riethdorf S, Pantel K. Circulating tumor cells and bone marrow micrometastasis. Clin Cancer Res 2008; 14:5013-5021. 